\title{
Understanding the drivers of subsistence poaching in the Great Limpopo Transfrontier Conservation Area: What matters for community wildlife conservation?
}

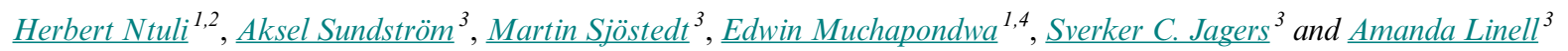

\begin{abstract}
Although subsistence poaching is a large threat to wildlife conservation in Southern Africa, this behavior is seldom researched. Our understanding of individual and community level factors that drive such behavior is limited because of both lack of data and the literature's predominant focus on commercial poaching. The main objective of this study is to contribute to this scanty literature by examining the factors that are correlated to subsistence poaching in the Great Limpopo, a transfrontier reserve spanning across Mozambique, South Africa, and Zimbabwe. We use collected primary data from a sample of 2282 respondents and 85 villages that are part of the transfrontier conservation area. We focus on two features, reported subsistence poaching incidences in the community and the previous hunting of individuals, a behavior that is now forbidden in this area. We find through multivariate regression analysis that the likelihood for reported poaching incidences was higher in communities with a larger proportion of young men, plenty of wildlife, and experiencing wildlife conflict. In addition, our survey results illustrate that there is less poaching in communities where local people trust each other, respect institutions, perceive that the management of the park is good, and view wildlife as an asset. Some of these variables can be influenced by appropriate interventions; our findings suggest that capacity building in local institutions, use of community-based crime prevention approaches, training related to wildlife management, and public awareness campaigns could be used by policy makers to affect individuals' perceptions and behaviors in this context.
\end{abstract}

Key Words: common pool resources; community institutions; Mozambique; South Africa; subsistence poaching; wildlife conservation; Zimbabwe

\section{INTRODUCTION}

Poaching of plants and wild animals in general constitutes a severe threat to biodiversity and to the livelihoods of poor communities around the world. From the literature addressing wildlife crime, poaching is generally viewed as the illegal practice of entering another's property to hunt or steal game without permission (Kahler and Gore 2012, Kahler et al. 2013, Harrison et al. 2015). As shown by Kahler and Gore (2012), plants and wildlife subjected to poaching often experience decreases in abundance, range collapse, and extinction, which in turn pose severe challenges to ecosystem functions. The consequent loss of biodiversity may also jeopardize livelihoods by affecting food security and the security of rural and peri-urban economies dependent on wildlife tourism (Kahler and Gore 2012, Mabele 2017).

Poaching is, however, a multifaceted phenomenon with many potential drivers, ranging from the subsistence requirements of individual poachers to availability of opportunities in international markets for commercial poachers and crime syndicates selling illegal wildlife trophies (Hübschle 2017, Lunstrum and Givá 2020). There are several theoretical frameworks that add value to the conceptualization of environmental crime in general, and in particular to poaching, such as the social exchange theory, environmental criminology theories (e.g., rational crime theory and routine crime theories), behavioral economics, and various social-ecological systems (SESs) frameworks. Although these theories overlap, they bring in different flavors to the literature and thus deserve to be looked at in detail.
There are two types of poaching: subsistence and commercial. In the literature, subsistence poaching is thought to be conducted by local poor households, whereas commercial poaching is done by wealthy people working in collaboration with local communities (Muchapondwa and Stage 2015, Ntuli and Muchapondwa 2018). Unlike commercial poaching, which occurs mainly inside protected areas, subsistence poaching is mostly conducted when wildlife is roaming in the buffer zones and on communal land. However, as the wildlife population roaming outside protected areas gets depleted, subsistence poaching tends to occur also inside the protected areas (e.g., Lindsey et al. 2013, Obour et al. 2016).

Although commercial poaching is a serious problem, as reflected in national and global biodiversity statistics, subsistence poaching may-in the absence of proper institutions to control illegal behavior - also result in equally disastrous outcomes for localized species and SESs (Lindsey et al. 2013, Ntuli and Muchapondwa 2018). Estimates hold that the value of bushmeat sold on the local market in Africa, as a safety net to smoothen drops in household income or consumption (e.g., Kiffner et al. 2015), could be worth several millions of U.S. dollars, with the bulk of this trade taking place in West African countries (Schulte-Herbrüggen et al. 2013). These statistics provide a good indication of how serious subsistence poaching is in Africa.

We lack knowledge of the who and why, related to subsistence poaching because of limited availability of data and empirical work. $^{[1]}$ The characteristics of subsistence poachers are not known; e.g., are poor people more inclined to poach compared to wealthier people? Furthermore, it is not well understood what

${ }^{1}$ School of Economics, University of Cape Town, South Africa, ${ }^{2}$ WWF South Africa, ${ }^{3}$ Department of Political Science, University of Gothenburg, Sweden, ${ }^{4}$ Department of Business Administration, Technology and Social Sciences, Luleå University of Technology, Sweden 
motivates poachers to poach; e.g. is it the presence of poor institutions and corrupt park officials (H. Ntuli, E. Muchapondwa, N. Banasiak, et al. 2019, unpublished manuscript) or their marginalization by the system (Hübschle 2016, 2017)? As a result, the weight that should be given to ecological, socioeconomic, community, and institutional variables as drivers or possible solutions of subsistence poaching is unknown (Ntuli and Muchapondwa 2018).

Taking the resulting loss of biodiversity, "eroding our own life support system from under our feet" (see Steffen 2012, Ayling 2013), as our starting point, we set out to empirically investigate the underlying drivers of subsistence poaching identified from the literature. We use unique survey data collected from the Great Limpopo Transfrontier Conservation Area (GLTCA), which includes three national parks in Mozambique, South Africa, and Zimbabwe, and focus on a research gap associated with individual- and community-level drivers of subsistence poaching. More specifically, we address three important issues in the common pool resource (CPR) literature and pose the following questions:

1. What are the factors driving subsistence poaching behavior in local communities around the GLTFCA?

2. What are the characteristics of individuals who are likely to violate hunting rules?

3. What measures can be instituted to counter the drivers of subsistence poaching?

Using an original survey of over 2200 respondents from the GLTFCA, our findings indicate that the likelihood for reported poaching incidences was much higher in communities with a higher proportion of young men, plenty of wildlife, and experiencing wildlife conflict. There is less poaching in communities where local people trust each other, respect institutions, perceive that the management of the park is good, and view wildlife as an asset. In addition to individual characteristics, other variables relevant for policy also matter in explaining the observed variation in subsistence poaching across countries. The findings confirm a general expectation, that the number of reported subsistence poaching incidences is higher for communities in Mozambique than it is for communities in South Africa and Zimbabwe. Moreover, focus group discussions with local communities in Mozambique revealed that subsistence poaching is not generally viewed as an offence by these communities, because it involves less valuable species. There is also a widespread perception that the judicial system is ineffective.

The implication of our results is that appropriate interventions such as capacity building and training to strengthen local institutions can be used to achieve the desired conservation outcomes by targeting relevant variables, e.g., by rolling out awareness campaigns in local communities around the GLTFCA and conducting training related to natural resource management (NRM). There is also a need to promote conservation partnerships or develop appropriate comanagement models involving local communities and the state or the private sector that are tailored to suit local conditions. Policy makers should start experimenting with community-based policing approaches such as the use of community rangers to service the community.

\section{THEORY AND CONCEPTUAL FRAMEWORK}

Illegal harvesting of wildlife resources, that is, harvesting in violation of laws or formal rules, is by many researchers viewed as the biggest challenge threatening conservation efforts in developing countries (Keane et al. 2008, Gandiwa et al. 2013, Tranquilli et al. 2014, Kiffner et al. 2015). Although the literature seems to suggest that the drivers of commercial and subsistence poaching sometimes overlap, we acknowledge the limitation in extrapolating or relying on the work of previous studies, whose focus is on commercial poaching, because the motives behind these activities are different (e.g., Hübschle 2017, Lunstrum and Givá 2020). In general, poaching is deeply embedded in culture as an activity that has been passed on from generation to generation (Hübschle 2016, 't Sas-Rolfes et al. 2019). Subsistence poaching may also stem from human-wildlife conflicts where crop damage or livestock depredation motivate retaliatory or preventive poaching (Givá and Raitio 2017). According to Hübschle (2017), commercial poaching can also manifest itself as an act of social defiance, symbolic protest of local management practices, or as an act of rebellion toward specific laws or state authority in general, which she refers to as "contested legality." It also happens because of the need for households to cushion themselves against poverty and shocks, for income generation, to supplement household nutrition, or because of cultural or traditional beliefs. Theoretically, these diverse motivations may coincide, resulting in negative or positive feedbacks, but the underlying drivers have rarely been evaluated in empirical research. This research gap is especially true with regard to the type of behavior in focus in this article, subsistence poaching, which we see as the illegal harvesting of wildlife resources primarily for household consumption or for limited local trading.

Different theoretical frameworks exist that help us to conceptualize environmental crime and we now proceed to discuss these theories, e.g., the social exchange theory, environmental criminology theories, behavioral economics, and various SESs frameworks. Having its origins grounded in social science, the social exchange theory developed by sociologist Homans' (1958) study on social behavior in the interaction of two parties that implement a cost-benefit analysis to determine risks and benefits. It proposes that social behavior is the result of an exchange process. The purpose of this exchange is to maximize benefits and minimize costs. According to this theory, people weigh the potential benefits and costs of social relationships and act in accordance with this calculation.

Rational choice theory posits that criminal actions are the outcomes of rational decision-making processes (Clark 1990, Milner-Gulland and Leader-Williams 1992, Leader-Williams and Milner-Gulland 1993, Perman et al. 2003, Fischer et al. 2011). Like in the social exchange theory, individuals are assumed to weigh costs and benefits of committing a crime, where the costs and benefits are functions of variables that can be influenced by policy interventions and of some that cannot. Under the assumption of rationality, the theory predicts that crime will be committed if the benefits outweigh the costs of committing a crime. If the assumption of rationality is relaxed, the theory breaks down and other theories are needed to explain behavior under these conditions. Furthermore, there are variables that enter both the cost and benefit functions that are unobservable, which makes it difficult to trace behavior to a specific variable. 
A useful way to distinguish between various crime prevention theories is to look at whether they are focused on the offender or the offence (Cornish and Clarke 2008). These theories focus on reducing the opportunity to commit a crime and they include situational crime prevention (SCP), problem-oriented policing (POP), and routine activity theory (RAT). A different strand of literature looks at normative approaches and their utility in understanding poaching (Carter et al. 2017). Normative approaches seek to understand the role of norms and values in justifying rule-breaking behaviors (Carter et al. 2017). Our understanding of community-oriented policing and communitybased crime-prevention approaches is poor because of limited adoption and experimenting with such mechanisms in Southern Africa's wildlife sector (Ntuli and Muchapondwa 2018). Similar approaches are considered in fields such as behavior change, community development, economic empowerment, and therapeutic interventions.

While recognizing these partly overlapping theoretical angles, the conceptual framework that we utilize for this study is primarily informed by the theory used for analyzing complex SESs, developed by Ostrom (2007). It fits very well with the communitybased natural resource management (CBNRM) context relatively prevalent in African countries. The theory identifies eight core components that are linked together and arranged into a threetier system. The third tier is made up of the external environment such as economic, political, and social forces in addition to other linked ecosystems such as rivers and woodlands. The second tier consists of the resource system such as a transfrontier conservation area (TFCA), resource units, i.e., a fugitive resource such as wildlife, resource users such as local communities and tourists, and the governance system that is made up of community institutions and rules governing the park. The first tier is called the action domain where the various components interact to produce outcomes. These outcomes can either be desirable or undesirable depending on whether it is below, above, or at the social optimum level. This study focuses on what happens in the first tier of this framework as subsistence poaching occurs in the action domain. However, what happens in the first tier is also influenced directly or indirectly by variables in the second and third tier. Figure 1 illustrates the conceptual framework used in this paper.

Table 1 puts Ostrom's theorem into perspective. We ignore variables in the third tier because these are more difficult to control and lie outside the influence of local communities. We can think of variables in the second and third tier as being interwoven in a web that links each variable to another. Of course, some of these relationships are unidirectional as we do not expect variables in the second tier to affect variables in the third tier, while other variables are bidirectional, especially variables in the same tier. In our context, we consider localized wildlife species such as antelopes that move freely in the TFCA and interact with local communities when roaming outside protected areas. The interaction between the community and the resource units sometimes produces undesirable outcomes. For instance, members of the community may overexploit the resource because wildlife poses a threat to their livelihoods through livestock predation, destruction of field crops, and sometimes by causing injuries, or even deaths, to human beings. Sometimes, members of the community believe they own wildlife and therefore overexploit it once it is outside protected areas.
Fig. 1. Framework for analyzing social-ecological systems.

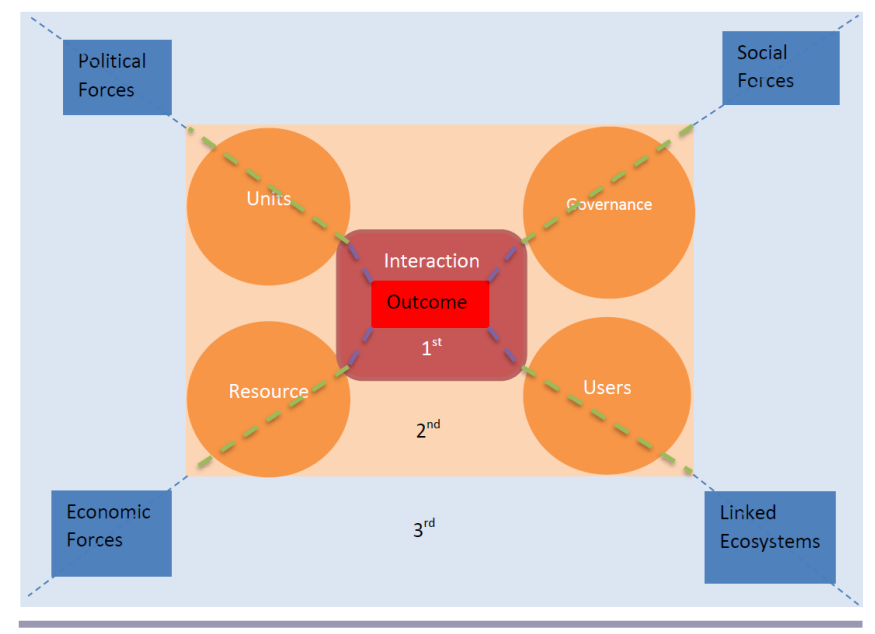

\section{Expectations}

Being a fugitive resource and characterized by the features of CPRs, the status of wildlife populations tends to be associated with uncertainty. Resource users are not sure if the resource will be there tomorrow: someone else might harvest the resource after they have conserved it or conservation institutions might become more strict, making future harvests impossible. If the communities in question are without the means of controlling extraction, then the end result is resource overexploitation and possibly the total collapse of the SES. The prediction of resource degradation usually comes true in a very large and highly valuable resource system under open access conditions when users are diverse, do not communicate, and have failed to develop institutions for managing resources (Agrawal 2001, Ostrom 1990, Ostrom et al. 2007). We argue that even with less valuable resources, if the community believes that there is plenty in the protected areas, they tend to overexploit the resource. Local communities are hence expected to exhibit a myopic behavior if they do not benefit from the resource (Johannesen and Skonhoft 2004). Moreover, unless they are made to benefit from the resource, local communities can sabotage government conservation initiatives. In this paper, we consider subsistence poaching as a collective action problem and as such it can be viewed as lack of cooperation among community members. In this case, the whole community forms a view about whether subsistence poaching is tolerable or not, and this affects the costs that individuals suffer when they make a decision to go poaching (Ostrom 2007). Thus, in addition to user characteristics, we also expect those variables that facilitate collective action to influence the community's subsistence poaching behavior. For this reason, some of the variables we use in our models also come from the second tier.

Theoretically, community variables, institutions, ecological conditions, and household characteristics such as age, gender, education, income, and employment have been observed to influence the destructive or illegal behavior in natural resource management (Ostrom et al. 2007). Agrawal (2001) documented more than 30 variables that had been posited in major theoretical and empirical work to affect incentives, actors, and outcomes 
Table 1. Second tier variables used.

\begin{tabular}{ll}
\hline \hline Resource System & Governance System \\
RS1: Sector - wildlife sector & GS1: Wildlife Management Committee \\
RS2: Resource size - finite & - Expected to continue with conservation outside park \\
RS3: Renewable resource & GS2: State \\
RS4: Resource type - small wild animals & - Enact bylaws and sometimes monitoring \& \\
& enforcement \\
& - Has the rights to wildlife (who benefits?) \\
& - Collects and distributes revenues (is system fair?) \\
& GS3: National Parks \\
& - Custodian of wildlife \\
& - Set hunting quotas or impose total hunting ban \\
& - Monitoring \& enforcement inside protected area \\
Resource Units & Users \\
RU1: Fugitive resource & U1: Large number of users + user attributes \\
- Wildlife destroy crops and livestock & U2: Conflict of interest \\
RU2: Legal harvesting and tourism & - Maximize community welfare (altruistic motive) \\
- Generate income to the community & - Maximize short-term gain (self-interest) \\
RU3: Illegal harvesting by poachers & - Nuisance motive for harvesting wildlife \\
Interaction & \\
I1: Maximum harvesting levels by poachers & Out: Poaching leads to resource overexploitation \\
I2: Crop damage and livestock predation & O2: Destruction of the ecological system \\
\hline Source: adapted from Ostrom (2007) &
\end{tabular}

Source: adapted from Ostrom (2007)

related to sustainable governance of a resource system. Based on our conceptual framework, because the communities in the study area are similar in terms of their socioeconomic attributes, we expected community variables, institutions, and ecological conditions to play a more important role in explaining behavior at both the community and the individual level than the socioeconomic variables. Specifically, we expected the impact of household variables to be less pronounced or the variable to be insignificant if used in a regression model. We expected subsistence poaching to increase with group size and resource quality or abundance. Finally, we expected subsistence poaching activities to be low in communities with good institutions.

\section{THE HISTORY OF THE GLTFCA}

Contextually, the history of subsistence poaching in different communities and countries in the study area is similar in some aspects and different in others. To expose these similarities and differences, we describe the history of the creation of national parks in the three countries and then conclude with the events that led to the establishment of the GLTFCA. Kruger National Park (KNP) in South Africa is the first park to be established in the study area, by the President of then Transvaal, Paul Kruger, in 1898. This was followed by the establishment of Gonarezhou National Park (GNP) in 1936, as a game reserve, eventually being proclaimed a national park in 1975 . The Limpopo National Park (LNP) in Gaza Province of Mozambique was born when the status of the wildlife utilization area (Coutada), which started in 1969, was changed from a hunting concession to a protected area in 2001 (Milgroom and Spierenburg 2008, Milgroom 2015, Massé 2016).
The creation of national parks in the GLTFCA came about as a result of the realization that wild animals needed to be protected by restricted hunting (Massé and Lunstrum 2016, Muboko 2017, Lunstrum and Givá 2020). Hunting restrictions came in the form of policies, laws, and legislations, which only recognized hunting in certain areas if appropriation rights and quotas were awarded by the responsible state authorities, while at the same time criminalizing subsistence and illegal trophy hunting by both unauthorized and local people (Mavhunga 2014, Annecke and Masubelele 2016). Furthermore, the law allowed trophy hunting on private game reserves, while it was forbidden in protected areas and on communal land. Legal trophy hunting was justified as sustainable use that contributed to the survival of other species by investing the proceeds into conservation ('t Sas-Rolfes et al. 2019). Certainly, this benefited the landowners and the private game farming community at the expense of local communities. For instance, in Zimbabwe, appropriation rights are given to landlords with wildlife on their property, while in South Africa the law recognizes the rights to wildlife if it is found on private property. Of course, there are other conditions that need to be satisfied in order to claim the rights to wildlife because it is a fugitive resource, i.e., fencing of the property, providing statistics that will feed into the calculation of the quota, and continuing with the conservation work (Ntuli et al. 2019). Therefore, the history of the criminalization of local hunters in the three countries cannot be divorced from the creation of LNP, KNP, and GNP. As a result, local people felt marginalized because they were not allowed to benefit from a resource that is part of their heritage. More specifically, studies suggest that these communities do not view the wildlife policies and laws as fair and morally right because they were not part of their creation, they are refused 
access to a resource that originally belonged to their ancestors, and they also bear the burden of living with wildlife (Milgroom 2015, Hübschle 2017, 't Sas-Rolfes 2017, Givá and Raitio 2017, Witter and Satterfield 2019).

The creation of national parks in the study area has been associated with nullifying local people's property rights to wildlife, and also characterized by dispossession of local communities from their ancestral land (Muchapondwa and Stage 2015, Lunstrum 2016, 't Sas-Rolfes 2017). Because these events took place during the colonial epoch in South Africa and Zimbabwe, the removal of people from the protected areas was violent and forceful (Muchapondwa and Stage 2015, Lunstrum 2016, 't SasRolfes 2017). According to Hübschle (2016), this left a permanent scar on the communities in question that is passed on from generation to generation. Without mending the relationship between these local communities and protected areas, it is difficult to instill discipline and a sense of stewardship (Mavhunga 2014, Massé 2016, Hübschle 2016, 2017). In Mozambique, the process is different because the establishment of LNP was much more recent compared to the other two national parks. The removal of local communities residing inside LNP has been a very slow and painstaking process because of lack of resources, politics, resistance, and the need to observe human rights (Challender and MacMillan 2014, Lunstrum 2013, 2016, Massé et al. 2017, Ntuli et al. 2019).

Scholars believe that the historical context and many other conditions that will be examined in this study exacerbate poaching in the study area (Lunstrum 2016, Massé and Lunstrum 2016). As a result of previously failed colonial policies, different CBNRM programs have more recently been implemented in order to engage local communities in wildlife conservation, i.e., benefitsharing schemes such as CAMPFIRE in Zimbabwe and Makuleke contractual park in South Africa. On the Mozambican side, the CBNRM arrangement is still taking shape with different scholars advocating for the aforementioned benefit-sharing schemes or the conservancy model as in Namibia (e.g., Ntuli et al. 2019). Community engagement and comanagement approaches are seen as the gateway to success and eradication of subsistence poaching and poverty in the region. In this relatively new development paradigm, local communities are recognized as important stakeholders and agents of change in the creation of a regional development initiative that includes the state and the private sector. It is believed that regional development initiatives such as these will achieve some of the sustainable development goals through unlocking and creating new opportunities associated with private-public partnerships and economies of scale in addition to re-establishing or reclaiming wildlife habitat and migration routes that have been lost as a result of human activities such as agriculture and urbanization, which in turn has led to habitat fragmentation (Massé 2016, Givá and Raitio 2017, Muboko 2017). It is also believed that commercial and subsistence poaching will decrease once better alternative livelihood activities are available to local communities (Lunstrum and Givá 2020; H. Ntuli, E. Muchapondwa, N. Banasiak, et al. 2019, unpublished manuscript). This has been the motivation for the creation of the GLTFCA, which merges LNP, KNP, and GNP.

The GLTFCA is an extensive network of conservation areas straddling the borders of Mozambique, South Africa, and
Zimbabwe with the GLTP at its core (Lunstrum 2013). The areas adjacent to the GLTP, but not necessarily formally integrated into it, are managed as part of the GLTFCA. This also implies that local communities are included in the TFCA. The GLTP was officially established in 2000 , when a common treaty was signed between the governments of the three countries (Sundström et al. 2020). A new agreement was approved in 2002, recognizing the "core protected areas" of the region and thereby establishing the GLTP. It currently stretches over an area of about $35,000 \mathrm{~km}^{2}$, but the future plan for the TFCA is to expand into surrounding areas covering approximately $100,000 \mathrm{~km}^{2}$ and thereby becoming one of the world's biggest TFCAs (Ntuli et al. 2019). This also implies that local communities are included in the TFCA. The main objective of GLTFCA is to foster transnational collaboration and increase the effectiveness of ecosystem management. Ideally, it was supposed to provide free movement of both tourists and wildlife within the TFCA. Aside from that, another important purpose is for the local communities to receive economic benefits through increased eco-tourism in the region. The GLTFCA is envisioned to generate economies of scale though public-private partnerships and supplying a much larger habitat for fugitive resources such as elephants.

\section{RESEARCH METHODS}

\section{The study area}

Figure 2 shows a map of the GLTFCA, where the national parks are shown in dark green and neighboring communities situated in the region are shown in light brown. The GLTP is located between $22^{\circ} 22^{\prime} \mathrm{S}$ and $31^{\circ} 22^{\prime} \mathrm{E}$, with arid conditions and is thus less suitable for rain fed agriculture (Gandiwa 2011, Ntuli and Muchapondwa 2018). Mozambique and Zimbabwe have predominantly rural communities and South Africa has periurban communities. The production technology in the former two countries is predominantly subsistence in nature combining livestock rearing and crop cultivation. In South Africa, livestock production is the dominant activity. The population in the study area is dominated by Shangani speaking people (over 95\%) although other languages such as Shona, Ndau, Ndebele, Venda, and Zulu are also spoken (Ntuli et al. 2019). Although bearing some differences, the culture and ecological conditions are more or less the same across the communities. In Mozambique and Zimbabwe, households depend heavily on income from landbased resources and remittances from relatives working in South Africa, while in South Africa they depend on employment income and social grants (Ntuli et al. 2019). Although unemployment is generally very high across the region, it is higher in Mozambique and Zimbabwe than in South Africa (Ntuli et al. 2019).

On the Zimbabwean side, local communities are organized into CAMPFIRE projects. CAMPFIRE communities in Zimbabwe do not own land inside the protected area but manage wildlife traversing the adjacent buffer zone through their respective rural district councils (RDCs). The proceeds from wildlife conservation in Zimbabwe are then shared between the RDC and the CAMPFIRE communities. CAMPFIRE communities receive approximately $50 \%$ of the revenue from trophy hunting, 3\% goes to the CAMPFIRE association, while the RDC retains $47 \%$ of the proceeds (Ntuli and Muchapondwa 2018). In South Africa, the Makuleke community owns land inside the KNP, but hires a safari operator to manage tourism activities on the community's 
Fig. 2. Map of the Great Limpopo Transfrontier Conservation Area. National parks are shown in dark green and neighboring communities situated in the region are shown in light brown.

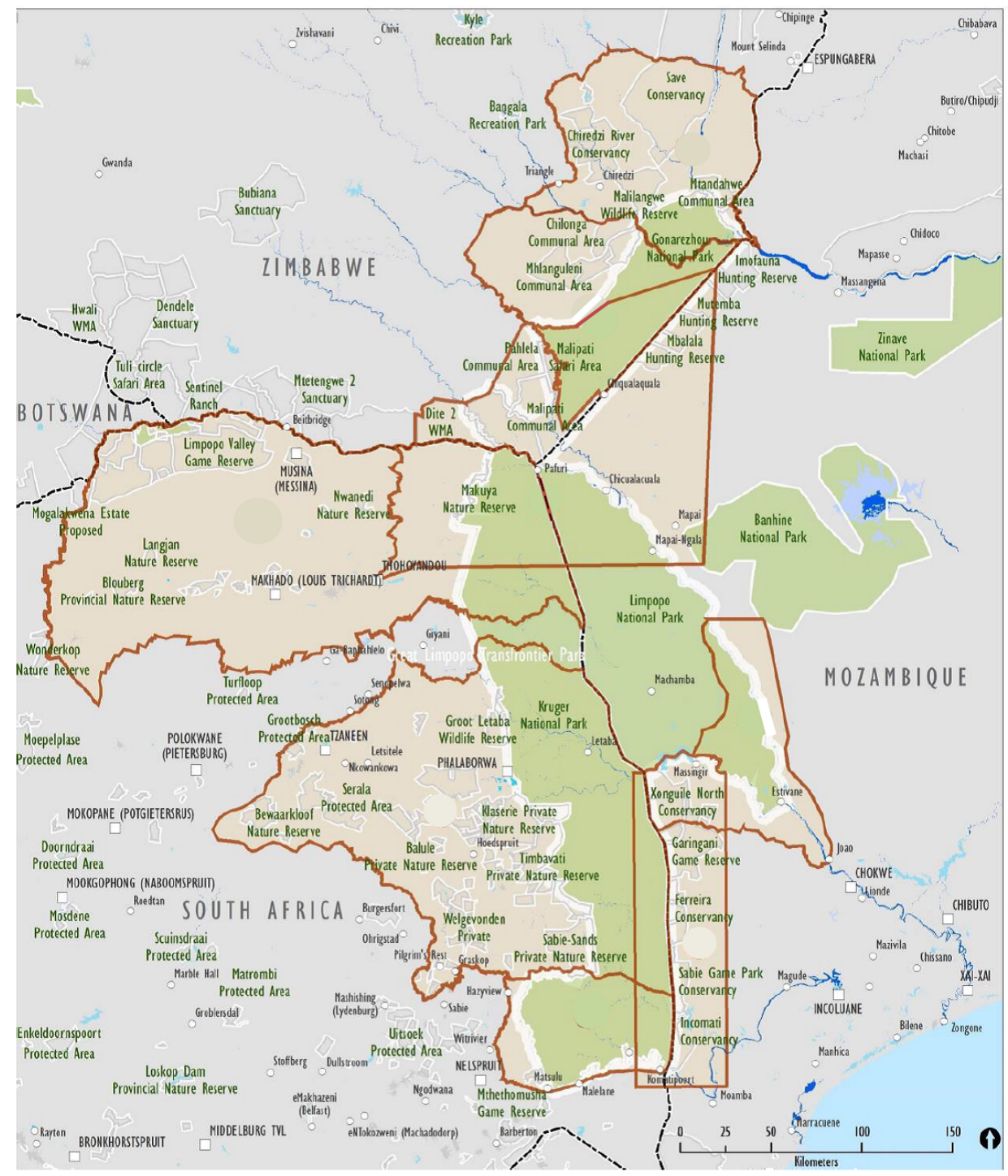

behalf, while they have an arrangement with SANParks to manage wildlife (Ntuli et al. 2019). The revenues are shared between Makuleke and the safari operator. In Mozambique, the park agency shares $20 \%$ of the revenues generated from wildlife conservation with local communities (Lunstrum 2016, Givá and Raitio 2017).

\section{Research design and data collection}

We largely employ a quantitative approach to investigate our research questions, which is supplemented by some qualitative insights where important gaps exist. Quantitative data was collected through an original household survey, while qualitative information was collected through a series of focus group discussions (FGDs) and key informant interviews with experts or key resource persons in the study area.
For the survey, our sampling approach was based on a multistage sampling, in which a combination of different sampling methods was employed. First, stratified sampling (with each country considered a required stratum) was used to ensure appropriate representation across the three countries. Second, within each country, we used cluster sampling whereby every geographic unit was assigned to one cluster, then a sample of clusters to be surveyed being chosen randomly. Thus, only households within sampled clusters were eligible to be surveyed. Third, we used systematic random sampling in each cluster.

The unique survey data was collected between May 2017 and June 2018 using face-to-face interviews. The survey targeted the head of the household on the understanding that she or he would give a representative view of the household. The survey consisted of questions on the respondents' socioeconomic conditions and themes, such as willingness to follow formal rules, law 
enforcement, and the function and management of the park. Furthermore, we asked about poaching behavior of individuals and the community, i.e., the number of confirmed poaching incidences in the community that respondents had heard about and the last time the respondents were actually engaged in hunting activities.

In Zimbabwe, 11 out of 29 CAMPFIRE communities located near Gonarezhou National Park in Chiredzi Rural District were chosen. In South Africa, 5 villages closely situated to Kruger National Park were selected. On the Mozambican side, 21 villages in three administrative areas located in two districts close to LNP were selected. The data includes 2282 respondents, with 769 respondents from Zimbabwe, 582 respondents from South Africa, and 931 respondents from Mozambique. Table 2 shows the sample statistics.

Table 2. Sample size.

\begin{tabular}{lcc}
\hline \hline Country & Freq. & Percent \\
\hline Zimbabwe & 769 & 33.70 \\
South Africa & 582 & 25.50 \\
Mozambique & 931 & 40.80 \\
Total & 2282 & 100 \\
\hline
\end{tabular}

Source: survey data May 2017-June 2018.

\section{Empirical model specification}

We empirically tested a model of subsistence poaching in local communities around the GLTFCA on the drivers identified in the literature. The analysis was accomplished by running two models whose results speak to each other and, as such, should not be viewed separately, but as part of a structural framework. While the dependent variable in the second model actually measures the household's own poaching activity, the first model measures poaching by everyone else in community, except the respondent. Our choice of dependent variables used in the two models was based on the sensitive nature of the study and the difficulty in collecting poaching data. Consistent with theory and empirical literature, we assumed that subsistence poaching is a function of socioeconomic, ecological, community, and institutional variables, in addition to how respondents perceive wildlife and conservation in general.

For the first model, we used the reported number of poaching incidences in each community as the dependent variable. This measure gauges the individual perception of group behavior. Thus, the question used in the survey allowed respondents to talk about the poaching activities of others in the community, i.e., N-1. This strategy avoids judging the respondent, but gives them a platform to talk about others in strict confidence. Because the dependent variable is measured at community level, we made use of community averages in the first model. We acknowledge the limitation of using this indicator to examine the actual group behavior we aim to study.

The original model potentially includes a latent dependent variable because some respondents might choose not to report poaching. The dependent variable in the estimated model has both positive values and zeros (particularly from liars). For this reason, we fitted a craggit model on the reported number of poaching incidences as a function of socioeconomic, ecological, community, and institutional variables. It jointly estimates a probit model on whether or not respondents have a positive value and then a linear regression model for those who have positive values (Engel and Moffatt 2014). The probit model tells us the likelihood that a respondent will report positive values of poaching incidences. We also computed the marginal effects to show the effect of the explanatory variables on our left-hand side variable when it was changed by a margin. Craggs double hurdle model is a two-stage Tobit model and a modification of the Heckman model, which is more flexible and accommodates some bias resulting from lying (Yen and Huang 1996, Engel and Moffatt 2014).

For the dependent variable in the second model, we solicited information about the last time (month and year) the respondent was actively involved in hunting, where the unit of analysis for this model is the household. This formulation removes the stigma associated with breaking hunting rules by asking the respondent for their hunting data rather than poaching data. Next, the variable measuring the number of years that transpired since the household was actively involved in subsistence poaching activities is transformed into a binary variable in order to fit a logit regression model. The binary variable is created by defining a natural cut-off point linked to the creation of the CBNRM regime. By classification, those who stopped poaching after the inception of the CBNRM or lie dormant for more than $\mathrm{C}$ years are the conservationists, while those who continue poaching or remain active hunters after inception of the program are against conservation. To understand the attributes of individuals who are likely to be involved in subsistence poaching activities, we used a logistic regression model to examine the determinants of the probability that a respondent is an active poacher. Whether a respondent is a conservationist or not is unobservable, but what we observe is the individual's poaching behavior, i.e., $\mathbf{A}_{\mathrm{i}}=\alpha \mathrm{X}_{\mathrm{i}}+$ $\varepsilon$ and so $A_{i}=1$ if $A_{i}^{*}>0$, which implies that number of years $\leq$ $\mathrm{C}$ and zero otherwise.

We used the number of times a respondent went to bed without eating and whether the respondent's family was forced to sell assets as proxy for household shocks, while the variable expertise was captured by respondent's extraction of environmental resources. We used the latter to test whether people poach because they lack "alternative livelihoods" as claimed in the literature (Lindsey et al. 2013). We argue that households do not sell assets if there are other alternative ways of generating income. Table A. 1 in Appendix 1 shows the types of questions that were asked under the various themes. The variables measuring household shocks, expertise, institutions, and perceptions are computed indices recovered using factor analysis. Theoretical, empirical, and experimental studies suggest that socioeconomic characteristics (Baruch-Mordo et al. 2011, Kahler and Gore 2012, Knapp 2012, Moreto and Lemieux 2015), ecological attributes (Carter et al. 2017, Ntuli and Muchapondwa 2018), and community variables such as institutions (Challender and MacMillan 2014, Milgroom 2015, Ntuli and Muchapondwa 2018, Ntuli et al. 2019) affect community, household, and individual poaching behavior. Table 3 shows the explanatory variables used in our regression models and their expected signs. We acknowledge the limitations of these models in terms of addressing all the potential drivers of subsistence poaching and our interpretation will therefore be cautious. 
Table 4. Descriptive statistics.

\begin{tabular}{|c|c|c|c|c|c|c|c|c|c|}
\hline \multirow[t]{2}{*}{ Variable } & \multirow[t]{2}{*}{ Obs } & \multicolumn{2}{|c|}{ Zimbabwe } & \multicolumn{2}{|c|}{ South Africa } & \multicolumn{2}{|c|}{ Mozambique } & \multicolumn{2}{|c|}{ Total } \\
\hline & & Mean & Std.Dev. & Mean & Std.Dev. & Mean & Std.Dev. & Mean & Std.Dev. \\
\hline Age & 2282 & 43.04 & 15.11 & 42.19 & 15.01 & 42.05 & 16.47 & 42.42 & 15.65 \\
\hline Gender & 2282 & 0.390 & 0.488 & 0.282 & 0.450 & 0.322 & 0.467 & 0.335 & 0.472 \\
\hline Hhld size & 2282 & 6.209 & 2.532 & 4.627 & 2.115 & 7.073 & 3.765 & 6.157 & 3.165 \\
\hline Education & 2282 & 5.816 & 3.834 & 8.589 & 4.430 & 2.995 & 3.078 & 5.387 & 4.342 \\
\hline Group size & 2282 & 60.20 & 53.22 & 937.2 & 208.3 & 610.2 & 477.3 & 509.4 & 473.1 \\
\hline Electricity & 2282 & 0.01 & 0.133 & 0.91 & 0.292 & 0.02 & 0.121 & 0.243 & 0.429 \\
\hline Livestock & 2282 & 0.897 & 0.303 & 0.237 & 0.426 & 0.70 & 0.457 & 0.650 & 0.477 \\
\hline Employment & 2282 & 0.127 & 0.334 & 0.278 & 0.449 & 0.195 & 0.397 & 0.194 & 0.395 \\
\hline Grant & 2282 & 0.102 & 0.302 & 0.761 & 0.426 & 0.303 & 0.460 & 0.352 & 0.478 \\
\hline Shock index & 2282 & 0.550 & 0.498 & 0.142 & 0.350 & 0.374 & 0.484 & 2.438 & 6.501 \\
\hline Expertise & 2282 & 0.258 & 0.573 & 0.056 & 0.207 & 0.392 & 0.245 & 0.243 & 0.183 \\
\hline Plentywildlife & 2282 & 0.653 & 0.325 & 0.891 & 0.542 & 0.215 & 0.451 & 0.756 & 0.328 \\
\hline Benefits & 2282 & 0.941 & 0.481 & 0.467 & 0.493 & 0.012 & 0.458 & 0.253 & 0.435 \\
\hline Conflict & 2,382 & 2.341 & 0.241 & 0.037 & 0.013 & 2.052 & 0.347 & 0.129 & 0.435 \\
\hline Incidences & 2282 & 0.97 & 0.783 & 0.95 & 0.569 & 1.37 & 0.992 & 1.096 & 2.094 \\
\hline Lastpoach & 2.282 & 0.493 & 0.325 & 0.197 & 0.135 & 0.690 & 0.436 & 0.382 & 0.218 \\
\hline
\end{tabular}

Source: survey data May 2017-June 2018.

Table 3. Explanatory variables and their definition.

\begin{tabular}{|c|c|c|}
\hline Variable & Explanation & Expected sign \\
\hline Gender & $0=$ Female, $1=$ Male & - \\
\hline Education & Number of years in School & + \\
\hline Age & In years & + \\
\hline Household size & Number of household members & Undetermined \\
\hline Employment & Is respondent employed? & \pm \\
\hline Electricity & Access to electricity? $0=\mathrm{No}, 1=$ Yes & + \\
\hline Group size & How big is your community? & - \\
\hline Livestock & $\begin{array}{l}\text { Does respondent own livestock? } 0=\text { No, } \\
1=\text { Yes }\end{array}$ & - \\
\hline Social grant & Does respondent receive a social grant? & Undetermined \\
\hline Shock index & $\begin{array}{l}\text { Went to bed without food/forced to sell } \\
\text { assets }\end{array}$ & Undetermined \\
\hline $\begin{array}{l}\text { Plenty of } \\
\text { wildlife }\end{array}$ & $\begin{array}{l}\text { Is wildlife plentiful in your community? } \\
{[0,1]}\end{array}$ & \pm \\
\hline Conflict & $\begin{array}{l}\text { Number of times household suffered } \\
\text { wildlife intrusion }\end{array}$ & + \\
\hline Perception & $\begin{array}{l}\text { Perception about wildlife and good park } \\
\text { management }\end{array}$ & \pm \\
\hline Institutions & Community institutions & \\
\hline Expetise index & Expertise in resource extraction & Undetermined \\
\hline Benefit & $\begin{array}{l}\text { Respondent benefit from wildlife } \\
\text { conservation? }\end{array}$ & + \\
\hline
\end{tabular}

\section{Sample statistics}

The sample characteristics are provided in Table 4 . The average age in the total sample was 42 years. The respondents from Zimbabwe were on average slightly older than respondents from South Africa and Mozambique. Overall, there were more female respondents in the sample $(65.5 \%)$ in the study area. The Zimbabwean side had a significantly higher proportion of male respondents (39.0\%), while South Africa had the least $(28.2 \%)$. The respondents from South Africa were on average more educated (spent $\sim 8.6$ years in school), while their Mozambican counterparts had on average the least education (spent about three years in school). The average household size was slightly higher in Mozambique (seven members per family) and slightly lower in South Africa (five members per family) compared to Zimbabwe (six members per family). The group sizes for communities in South Africa were much higher on average ( 937 members per group), while those in Zimbabwe were much lower (60 members per group) compared to Mozambique (610 members per group). This difference emanates from the fact that the lowest administrative unit in the three countries is different. We define a community as the lowest political administrative unit in an area or country. In Mozambique and Zimbabwe, this refers to a village under the domain of a headman, while in South Africa it refers to as a tribal area or clan headed by a chief.

Approximately $91 \%$ of the respondents on the South African side had electricity, while less than $1 \%$ of respondents on the Zimbabwean and Mozambican side had access to electricity. Likewise, the proportion of respondents who were employed was also higher for South African communities (27.8\%) than it was for communities in Zimbabwe (12.7\%) and Mozambique (19.5\%). Respondents around GNP reported more household shocks $(55 \%)$ compared to respondents from the neighboring countries (48\% and $12 \%$ around LNP and KNP, respectively), while respondents around the LNP appeared to have more expertise $(39 \%)$ and hence depended more on environmental resource extraction than respondents around GNP $(26 \%)$ and KNP $(6 \%)$. About $76.1 \%$ of the respondents around KNP indicated that they received social grants, followed by $30.3 \%$ of respondents around LNP and lastly $10.2 \%$ of the respondents around GNP. About $94.1 \%$ of the respondents on the Zimbabwean side indicated that they benefitted from wildlife income, while $46.7 \%$ and less than $1 \%$ of the respondents on the South African and Mozambican side, respectively, indicated that they benefitted from wildlife conservation. The average number of reported poaching incidences was significantly higher for communities in Mozambique (1.4) than it was for communities in Zimbabwe (0.97) and South Africa (0.95). 
Table 5 shows that there are 561 observations with zeros reported for the number of poaching incidences. The full sample has 2282 observations, which means that 1721 are positive observations. As expected, the mean in the truncated sample is much higher than the mean in the full sample because of the effect of the zeros, while the reverse is true for the standard deviation or variance.

Table 5. Statistics for the full sample and truncated sample.

\begin{tabular}{lcc}
\hline & Full sample & Truncated sample \\
\hline Observations & 2282 & 1721 \\
Mean & 1.096 & 1.745 \\
Standard deviation & 2.094 & 2.428 \\
\hline
\end{tabular}

Source: survey data May 2017-June 2018.

\section{RESULTS AND DISCUSSION}

\section{Characterization of GLTFCA based on the sample statistics}

The descriptive statistics show that there were more female than male respondents in the GLTFCA, with respondents from South Africa having a better education. Consistent with Ntuli and Muchapondwa (2018) and Ntuli et al. (2019), we expected more female than male respondents from the study area because men are often employed elsewhere. We also expected the level of education in peri-urban communities in South Africa to be slightly higher relative to rural communities in Mozambique and Zimbabwe because communities in South Africa are relatively well developed compared to those in Mozambique and Zimbabwe. These differences in community orientation could have implications on resource extraction behavior and dependence. Furthermore, most people in the latter countries do not normally finish primary education because they prefer to cross the border into South Africa in search of jobs at a young age to fend for their families (Gandiwa 2011, Gandiwa et al. 2013, Ntuli et al. 2019). Our sample statistics support the idea that communities around KNP are better off than those around GNP and LNP in terms of many aspects that matter for welfare, i.e., good housing, access to electricity, clean water, and tarred roads. Additional information gathered during FGDs and key informant interviews revealed that CAMPFIRE communities are still experiencing severe hardships because of the economic crisis in Zimbabwe.

Prima facie, the data shows that there are slightly more humanwildlife conflicts in Zimbabwe than in Mozambique. However, a t-test reveals that the difference in the reported numbers of human-wildlife conflict between the two countries is not significantly different from zero. Local communities on the South African side are experiencing less conflict, possibly due to the effect of the fence around the KNP as well as effective management or quick response by the responsible authorities to wildlife intrusion in the community.

Our findings confirm a general expectation that the number of reported subsistence poaching incidences is higher for communities in Mozambique than it is for communities in South Africa and Zimbabwe. Even though Mozambique has far fewer wildlife populations compared with South Africa and Zimbabwe, we expected poaching incidences in the former country to be slightly higher relative to the latter two countries. Poaching in Mozambique may be exacerbated by poor CPR institutions, communities living inside the park (which makes it difficult to monitor what they are doing), and limited budget to fund antipoaching activities by the park agency (Lunstrum 2016, Massé 2016, Massé et al. 2017). Because of these weaknesses, local communities in Mozambique are also often used as entry points by poachers from other areas or countries (Ntuli and Muchapondwa 2018). In another study in Zimbabwe, Ntuli et al. (2019) observed that communities located very close to the game park sometimes act as if they own wildlife and treat it just like livestock roaming in their backyard. Given variability in individual, community, and institutional characteristics across countries, it is of great interest to examine if these differences also explain the variation in poaching behavior in the study area.

Identifying drivers of subsistence poaching and poacher attributes After this general overview of the results, we now answer and discuss our three research questions: (i) What are the factors driving subsistence poaching behavior in local communities around the GLTFCA? (ii) What are the characteristics of individuals who are likely to violate hunting rules? (iii) What measures can be instituted to counter the drivers of subsistence poaching? First we explain the models and discuss model fitness before we proceed to discuss the results.

Table 6 shows the results of the craggit model and logistic regression models. The third column of the craggit model shows the marginal effects. All models are highly significant at the 1\% level of significance. We observe that the variation in the dependent variables is explained by both ecological and community variables in addition to socioeconomic variables such as gender and age. The sign on the explanatory variables in both models agree most of the time and for this reason, we prefer to interpret the results of the two models together where appropriate to show the big picture. Our results demonstrate that policy variables such as perceptions, group size, and institutions also matter in explaining the observed variation in subsistence poaching across countries in addition to individual characteristics such as age and gender.

The results of the first stage of the craggit model suggest that the likelihood to report positive poaching incidences was much higher for communities with a higher proportion of men, plenty of wildlife, and those experiencing conflict, while the likelihood of reporting zero poaching incidences was higher in communities with good institutions, who benefited from wildlife conservation, perceived that the management of the park was good, where the level of trust was high, and in communities around the KNP and GNP. This was expected and consistent with other studies (e.g., Gandiwa 2011, Lindsey et al. 2013, Ntuli et al. 2019). In a recent study in the GLTFCA, Sundström et al. (2020) observed that women's attitudes to poaching generally are not divergent from men's. They found some differences among nonelectrified households and those with a dependence on resources; women were less likely to condemn commercial poaching and less willing to engage in antipoaching activities. Men in poorer households are more likely to know a poacher. The marginal effects in column 3 of the craggit model (Table 6) show that the number of poaching incidences either increases or decreases by at least one unit as we alter variables such as wildlife abundance, institutions, trust, conflict, and perceptions marginally. The coefficient for institutions has the highest magnitude, while the magnitude of the coefficients for wildlife abundance and conflict are almost 
Table 6. Regression analysis.

\begin{tabular}{|c|c|c|c|c|}
\hline \multirow[t]{2}{*}{ Variables } & \multicolumn{3}{|c|}{ Tobit model } & \multirow{2}{*}{$\begin{array}{l}\text { Logit Model } \\
(0=\mathrm{C}, 1=\mathrm{P})\end{array}$} \\
\hline & $\begin{array}{c}I^{s t} \text { Stage Probit } \\
\text { Model } \\
\end{array}$ & $\begin{array}{c}2^{\text {nd }} \text { Stage Trancated } \\
\text { Model } \\
\end{array}$ & $D y / D x$ & \\
\hline Education & $\begin{array}{l}0.0371 \\
(0.014)\end{array}$ & $\begin{array}{c}0.475 \\
(0.102)\end{array}$ & $\begin{array}{c}0.003 \\
(0.002)\end{array}$ & $\begin{array}{c}0.054 \\
(0.085)\end{array}$ \\
\hline Gender $[0=$ female, $1=$ male $]$ & $\begin{array}{l}0.273^{*} \\
(0.094)\end{array}$ & $\begin{array}{c}0.366^{* *} \\
(2.532)\end{array}$ & $\begin{array}{r}0.321^{* *} \\
(0.060)\end{array}$ & $\begin{array}{c}0.977 \\
(0.639)\end{array}$ \\
\hline Age & $\begin{array}{l}-0.003 \\
(0.004)\end{array}$ & $\begin{array}{l}-0.171 \\
(0.318)\end{array}$ & $\begin{array}{l}-0.012 \\
(0.007)\end{array}$ & $\begin{array}{l}-0.011^{*} \\
(0.057)\end{array}$ \\
\hline Employment $[0=$ no, $1=$ yes $]$ & $\begin{array}{l}0.117 \\
(0.114)\end{array}$ & $\begin{array}{l}-0.123 \\
(3.397)\end{array}$ & $\begin{array}{l}-0.836 \\
(0.070)\end{array}$ & $\begin{array}{l}0.236 \\
(0.177)\end{array}$ \\
\hline Livestock & $\begin{array}{c}0.046 \\
(0.024)\end{array}$ & $\begin{array}{c}1.955 \\
(1.425)\end{array}$ & $\begin{array}{c}0.067 \\
(0.029)\end{array}$ & $\begin{array}{c}0.236 \\
(0.684)\end{array}$ \\
\hline Kruger National Park & $\begin{array}{c}-0.385^{* *} \\
(0.128)\end{array}$ & $\begin{array}{c}-0.351^{* * *} \\
(2.293)\end{array}$ & $\begin{array}{c}-1.193^{* *} \\
(0.250)\end{array}$ & $\begin{array}{c}-0.490^{* * *} \\
(0.292)\end{array}$ \\
\hline Gonarezhou National Park & $\begin{array}{l}-0.253^{*} \\
(0.102)\end{array}$ & $\begin{array}{c}-0.753^{* * *} \\
(1.438)\end{array}$ & $\begin{array}{c}-0.448 * * * \\
(0.538)\end{array}$ & $\begin{array}{c}-0.129 * * \\
(0.001)\end{array}$ \\
\hline Shocks & $\begin{array}{l}0.017 \\
(0.008)\end{array}$ & $\begin{array}{l}-1.156 \\
(0.251)\end{array}$ & $\begin{array}{l}-1.516 \\
(0.126)\end{array}$ & $\begin{array}{c}0.053^{* *} \\
(0.170)\end{array}$ \\
\hline Expertise & $\begin{array}{c}0.140 \\
(0.023)\end{array}$ & $\begin{array}{l}-1.798 \\
(0.570)\end{array}$ & $\begin{array}{l}-0.741 \\
(1.413)\end{array}$ & $\begin{array}{c}0.186^{* * *} \\
(0.574)\end{array}$ \\
\hline Plenty of wildlife $[0=$ no, $1=$ yes $]$ & $\begin{array}{c}-0.363 * * \\
(0.102)\end{array}$ & $\begin{array}{c}-1.120 * * * \\
(0.489)\end{array}$ & $\begin{array}{c}-1.461^{* *} \\
(0.249)\end{array}$ & $\begin{array}{c}-0.719^{* * *} \\
(0.142)\end{array}$ \\
\hline Group size & $\begin{array}{l}0.021^{*} \\
(0.018)\end{array}$ & $\begin{array}{c}0.417^{* *} \\
(0.174)\end{array}$ & $\begin{array}{c}0.154^{* *} \\
(0.046)\end{array}$ & $\begin{array}{l}0.059 \\
(0.276)\end{array}$ \\
\hline Institutions & $\begin{array}{c}-0.773 * * * \\
(0.366)\end{array}$ & $\begin{array}{c}-1.255^{* * *} \\
(2.242)\end{array}$ & $\begin{array}{c}-1.782^{* *} \\
(5.044)\end{array}$ & $\begin{array}{c}-0.874 * * * \\
(0.348)\end{array}$ \\
\hline Trust & $\begin{array}{c}-1.694^{* * *} \\
(0.420)\end{array}$ & $\begin{array}{c}-0.392 * * * \\
(0.050)\end{array}$ & $\begin{array}{c}-0.992^{* * *} \\
(2.471)\end{array}$ & $\begin{array}{c}-0.879 * * \\
(0.500)\end{array}$ \\
\hline Benefits $[0=$ no, $1=$ yes $]$ & $\begin{array}{l}-0.684^{*} \\
(0.230)\end{array}$ & $\begin{array}{c}-0.328 * * * \\
(0.176)\end{array}$ & $\begin{array}{c}-0.160^{* *} \\
(0.137)\end{array}$ & $\begin{array}{c}-0.528 * * * \\
(0.376)\end{array}$ \\
\hline Conflict & $\begin{array}{c}0.575^{* *} \\
(0.341)\end{array}$ & $\begin{array}{c}0.439 * * * \\
(0.287)\end{array}$ & $\begin{array}{c}1.431^{* * *} \\
(1.528)\end{array}$ & $\begin{array}{c}0.437 * * * \\
(0.487)\end{array}$ \\
\hline Perception & $\begin{array}{c}-1.409 * * \\
(0.406)\end{array}$ & $\begin{array}{c}-1.731 * * * \\
(0.528)\end{array}$ & $\begin{array}{c}-0.974 * * \\
(0.370)\end{array}$ & $\begin{array}{c}-0.531 * * * \\
(0.528)\end{array}$ \\
\hline Cons & $\begin{array}{l}0.878^{*} \\
(0.232)\end{array}$ & $\begin{array}{c}-5.308 * * * \\
(1.168)\end{array}$ & $\begin{array}{c}-1,212 \\
1.53\end{array}$ & $\begin{array}{c}0.042 * * \\
(0.697)\end{array}$ \\
\hline Sigma & & $\begin{array}{c}1.368^{* * *} \\
(0.927)\end{array}$ & & \\
\hline Obs & 2282 & 1721 & 1721 & 2282 \\
\hline LR Chi2 / Wald Chi2 & 166.37 & 191.53 & & 181.42 \\
\hline Prob $>$ Chi2 & 0.000 & 0.000 & & 0.000 \\
\hline Pseudo R2 & 0.167 & 0.1853 & & 0.096 \\
\hline
\end{tabular}

Source: survey data May 2017-June 2018.

*Significant at $10 \%, * *$ significant at $5 \%, * * *$ significant at $1 \%$.

NB: The standard errors are shown in brackets.

similar. This result highlights the importance of CPR institutions in constraining poaching behavior and thus improving biodiversity outcomes (Saunders 2014). Our results demonstrate a cyclical and negative reinforcement between wildlife abundance and conflict on the animal population through poaching. Although there is more wildlife in communities that are less poached, there is more human-wildlife conflict, which in turn generates more incentives for poaching. Previous theoretical and empirical studies also suggest positive and negative feedbacks associated with different parts of the SES (Miller et al. 2012).

Considering the truncated sample, our results suggest that a community with a higher proportion of men is more likely to engage in poaching activities and vice versa. The logit model suggests that the likelihood to engage in poaching after the establishment of the CBNRM decreases as age increases.
Combining these two results we conclude that young men are more likely to poach than older men, while women and particularly older women exhibit proconservation behavior. A possible explanation why the activity is not part of the choice set for these two groups of resource users is that it is very risky and has a very high opportunity cost in terms of effort or time spent in prison if caught. The opportunity cost of forgone agricultural activities could be very high for older men with families to feed and it is even higher for women because of their responsibilities at home (Kahler et al. 2013; H. Ntuli, E. Muchapondwa, N. Banasiak, et al. 2019, unpublished manuscript). Furthermore, the reputation of women might be affected if they are caught. On the other hand, young men are risk loving and they can afford to invest plenty of time and effort in poaching if it is relatively profitable to do so, i.e., they do not have a reputation to protect and can sacrifice to spend some time in prison (Hübschle 2017). 
Hübschle (2017) observed that men also are more likely to engage in wildlife trafficking than women because it is a risky activity. Policy interventions should therefore target young men through the creation of alternative livelihood activities to divert their effort from poaching.

We observe that the coefficients on GNP and KNP are negative and highly significant in all the models. Hence, taking LNP as the baseline category, our results suggest that poaching by local communities around the other two national parks is lower relative to that of LNP. This result confirms what we established in the descriptive statistics. Furthermore, respondents from communities around KNP and GNP were less likely to be active poachers after the establishment of the CBNRM relative to respondents from communities living adjacent to LNP. This is not surprising for South Africa because the park is fenced and as a result there is less interaction between local communities and wildlife inside the KNP. Hunting is one of many criminalized practices to which people in this context turn in times of economic or political crisis (Mavhunga 2014). Ntuli et al. (2019) and Gandiwa (2011) observed that shocks and economic hardships in Zimbabwe force households to divert their effort from subsistence farming and other income generating activities toward poaching. According to the authors, the level of poaching in local communities around GNP could be comparable to that of communities around LNP because of economic hardships and opportunities presented by abundant wildlife on the Zimbabwean side.

Our results also illustrate that there is less poaching in communities where local people trust each other, respect institutions, perceive that the management of the park is good, and view wildlife as an asset. Furthermore, we are also less likely to find active poachers in such communities after the establishment of the CBNRM. In a study around the GNP, Ntuli and Muchapondwa (2018) found that CAMPFIRE communities are more likely to cooperate when good institutions are in place. FGDs and key informant interviews revealed less evidence of selforganization and the role of community institutions in wildlife conservation on the Mozambican side. This situation poses a serious threat to wildlife conservation not only in Mozambique, but in the GLTFCA at large. Although in South Africa there is a community board responsible for managing wildlife income, it is not representative of the communities in the study area. Ntuli and Muchapondwa (2018) found that there are about five communities around KNP claiming ownership of the conservation land inside the park, but only one of these five communities actually benefits from the contractual park arrangement.

According to the CPR literature, self-organization is a precondition for good environmental citizenry in poor communities (Baerlein et al. 2015, Hasanov and Zuidema 2018). It is argued that local communities that are able to develop robust CPR institutions are also able to manage their resources sustainably. The CPR literature also suggests that trust is an important ingredient that forms the social fabric for collective action (Saunders 2014, Becchetti et al. 2016). The role of trust in NRM via its influence on collective action is well documented in studies on water, forestry, and fisheries (Saunders 2014, Hasanov and Zuidema 2018). In the case of the GLTFCA, we expect those communities with high levels of trust to quickly self-organize in order to protect wildlife as the resource becomes depleted. On the other hand, lack of trust among resource users can result in overexploitation because of competition even if the resource is facing extinction (Ostrom 2010). This is a classic textbook example of an open access regime where resource users, in the absence of restrictions, will continue to mine a resource until the marginal costs exceed the marginal benefits.

Respondents who have expertise to extract environmental resources and who have experienced shocks such as chronic food shortages are more likely to be active hunters because of the need to either increase the intake of calories or supplement their diet. The two variables are not significant in the first model suggesting that expertise and shocks are only experienced by respondents at the household level rather than affecting the whole community. Communities around the GNP and LNP are made up of relatively poor people, whose livelihood strategies are heavily dependent on the environment (Lunstrum 2016, Muboko 2017, Ntuli et al. 2019). FGDs revealed that people around both national parks harvest environmental resources such as bushmeat, firewood, thatch grass, weaving and craft material, poles, wildlife vegetables, mopani worms, mushrooms, fruits, ancient Shangani wine called njemai, or uchema harvested from palm trees, etc. Most of these environmental resources are sold on both local and distant markets as raw or value-added products (Ntuli and Muchapondwa 2017).

It is undisputable that a policy instrument that seeks to increase devolution of NRM and consumption of environmental resources will enhance the welfare of local communities, but the real challenge is how to strike a balance between welfare and conservation objectives. If poaching is more prevalent in communities that have experienced shocks such as food shortages, then policy interventions that bring about resilience and are likely to meet the basic human needs of the households in the respective communities are required. For example, strengthening local institutions and creating sustainable livelihood opportunities will counter the impacts of both household shocks and communitylevel shocks to some extent, which in turn might translate into reduced subsistence poaching. Unlike commercial poaching, investment in alternative livelihood activities in local communities around the GLTFCA has huge potential to influence the decision of poachers to shift effort away from subsistence poaching toward better opportunities (H. Ntuli, E. Muchapondwa, N. Banasiak, et al. 2019, unpublished manuscript).

The results show a very strong link between resource quality and environmental extraction. Although there are fewer poaching incidences in a community where wildlife is plenty, the community members are also less likely to be active poachers after the establishment of the CBNRM. This is consistent with theory and expectations because reduced poaching is likely to translate into a healthy population of wildlife in communities that have good institutions (Baruch-Mordo et al. 2011, Muboko 2017). Kideghesho (2016) argues that plenty of wildlife in an area is a good indicator of a sound SES where users can manage their resources sustainably and efficiently. Carter et al. (2017) argue that abundant wildlife in an area can induce poaching because of the opportunities created to people that would otherwise not commit a crime if the chance was not there. This calls for tailormade policy interventions in order to strengthen local CPR 
institutions and prioritization of resources toward antipoaching enforcement in communities showing poor environmental husbandry in order to protect wildlife resources. Furthermore, there is also need for a better reward system for those communities that demonstrate good environmental stewardship to reduce incentives for poaching (Baruch-Mordo et al. 2011, Mabele 2017).

Another important driver of poaching in the literature that has received huge attention from many scholars is human-wildlife conflict (Hübschle 2017). Our results demonstrate that there is more poaching in communities with conflict and that community members were more active poachers after the onset of the CBNRM in these areas. Human-wildlife conflict is exacerbated by wildlife abundance and human encroachment into wildlife habitat in addition to poaching itself (Lindsey et al. 2013). Knell and Martínez-Ruiz (2017) observed that the social structure of most species living in groups is affected by killing either a dominant male or female (matriarch), which in turn might exacerbate conflict as the head responsible for bringing order or comprising the brains of the family is lost. As a result of conflict, it is believed that communities sometimes poach as a way of protesting or as revenge for the damages suffered (Carter et al. 2017). Scholars argue for alternative livelihoods through economic development as a solution to human-wildlife conflict in rural and peri-urban areas that are dependent on crop cultivation and livestock production.

In line with theoretical expectations, our results show that communities that consist of many people experience more subsistence poaching incidences and vice versa. This result is also consistent with empirical studies done in the region and elsewhere (Gandiwa et al. 2013, Cooney et al. 2017). A plausible explanation is that poaching might be rife in a larger group because of the resulting difficulties in monitoring (Ntuli and Muchapondwa 2018). We are also likely to find active hunters in very large groups because of difficulties in monitoring the resource and in exercising effective antipoaching enforcement. Under such circumstances, scholars argue that most governments in developing countries are not equipped to deal with such communities because of tight budget constraints that make it difficult to conduct effective monitoring and enforcement (Cooney et al. 2017). However, other studies find that extensive resources such as game parks and forests actually require a larger group size in order to efficiently monitor the resource (Ntuli and Muchapondwa 2018, Ntuli et al. 2019). A larger group size could, however, have a negative effect on wildlife in the presence of poor institutions (Ntuli and Muchapondwa 2018).

Pertaining to the insights from our focus groups, the FGDs with local communities in Mozambique revealed that subsistence poaching is not generally viewed as an offence by these communities because it involves less valuable species such as impalas, kudus, water bucks, inyalas, rabbits, birds, etc. 't SasRolfes (2017) noted that subsistence poaching has been part of the culture in local communities around LNP for a long time since independence and it is therefore very difficult to eradicate. Even park authorities and police condone such activities as evidenced by either insignificant penalties or lack of punishment for subsistence poaching or repeat offenders. Insights from our informant interviews revealed that the police tend to turn a blind eye maybe because they are aware of the socioeconomic context of the communities in the study area; this is happening particularly in Mozambique and Zimbabwe. A similar problem in the region is low conviction rates through the court system. These suggestive findings illustrate that the police service and judicial system in Mozambique and Zimbabwe needs transformation to embrace the conservation agenda rather than aligning with the community agenda. By the same token, people's perception about wildlife and park management is also important for collective action. Policy interventions such as training and awareness campaigns in the study area might help to change community perceptions and behavior in the long run.

Our findings do not only speak to previous theoretical and empirical accounts, but also to the history of GLTFCA and in particular, the creation of KNP, GNP, and LNP. The poaching behavior is closely linked to the history of the creation of protected areas, which included the forced removal of local people from their ancestral land in order to create national parks and the institutionalization of policies that marginalize communities in terms of access and ownership or property rights to wildlife. Mavhunga (2014) argues that wildlife conservation regimes have criminalized African hunting rather than enlisting hunters (and their knowledge) as allies to achieve sustainability in wildlife conservation. He argues that these practices need to be decriminalized and examined as technologies of everyday innovation with a view toward constructive engagement, innovating with Africans. Evidence show that there is less poaching in areas that either established good institutions or adopted the CBNRM concept earlier than those that came in later (Ntuli and Muchapondwa 2018). In such areas, the resource quality in terms of wildlife abundance is generally good because poaching reduced tremendously. Poaching in general reveals contestation, unhappiness, or that people do not recognize the legitimacy of the poaching laws. The fact that the state maintains de facto ownership and dominance over wildlife is highly contentious. Furthermore, the link between human-wildlife conflict and poaching can be interpreted as retaliatory behavior because communities have historically been denied access and ownership to wildlife, which in turn has resulted in frustration (Givá and Raitio 2017). Thus, addressing subsistence poaching is more than an enforcement problem (Challender and MacMillan 2014), i.e., to achieve good conservation outcomes entails engaging local people in conservation, creating better alternative livelihoods, and building institutional capacity and resilience in communities.

\section{CONCLUSION AND POLICY RECOMMENDATIONS}

Addressing subsistence poaching of wildlife is still one of the main tasks in wildlife conservation in Southern Africa. Our understanding of the subsistence poaching behavior is still limited because of a lack of data on these sensitive activities. To understand its motivation, we examine the correlation between subsistence poaching and its key drivers identified in the literature, such as socioeconomic factors, community, institutional, and ecological variables in order to inform wildlife policy in the region. These variables could be responsible for explaining the observed variation in subsistence poaching across countries and thus our analysis could be taken as confirmation of the drivers of subsistence poaching. The descriptive statistics confirm a general expectation that the number of reported subsistence poaching incidences is higher for communities in Mozambique than it is 
for communities in South Africa and Zimbabwe. We use both ordinary least squares estimation and logistic regression analysis to achieve our objective. Our results demonstrate that both community and policy variables such as community level trust, group size, the quality of local institutions, and people's perceptions of park management and wildlife are important variables that counter the real motivation for poaching. From the literature, some of the motivations for poaching are self-interest, human-wildlife conflict, retaliatory hunting, and protest behavior. There is also evidence of the role of socioeconomic variables such as age and gender on subsistence poaching.

The policy implication of this study is that appropriate interventions can be crafted to achieve the desired conservation outcomes by targeting relevant variables. Policy measures to counter the drivers of subsistence poaching come in many different forms. In general, policy reforms in terms of the legislation that regulate access to land and natural resources are required to create an enabling environment for local communities to participate and benefit from conservation. This will in turn yield the necessary conditions for the emergency of robust formal and informal CPR institutions needed to conserve wildlife. On the other hand, there is also need for policy makers and development practitioners to experiment with different types of community engagement and comanagement models that involve local communities and the state or private sector in addition to community-based crime prevention approaches.

At a higher level, addressing subsistence poaching requires joint efforts from the state, safari operators, and local communities, provided that the latter also benefit from wildlife conservation. This requires that all important stakeholders work together to achieve the common goal. Viewed from this angle, our results also speak to large-scale collective action to address subsistence poaching in GLTFCA. This higher level objective is only attainable if community institutions in different countries come together to form nested organizations at different levels of influence in order to stabilize large-scale cooperation that is needed to protect transboundary wildlife resources. The existence of community structures at different spheres of the GLTFCA governance system will enable them to contribute effectively toward policy formulation, decision making, and wildlife management in general.

At lower levels, local institutions need to be strengthened so that local communities are able to contribute meaningfully toward monitoring and enforcement in the community and buffer zone because it is cheaper for them to do so relative to doing it through the state apparatus. Community-based organizations such as traditional leaders need more recognition and strengthening in the area of enforcement to improve their legitimacy so that they are able to discharge appropriate or graduated sanctions thereby complementing state functions in this area. Strengthening both monitoring and law enforcement in the communities can also be achieved through the establishment of different types of institutions such as NRM committees, forums, and recruiting community rangers. This will in turn relax the state budget by freeing additional resources that can be employed inside the protected areas. If local communities are able to eradicate subsistence poaching, then the actual problem of the state is to fight commercial poaching.
Based on our results, we suggest increased investment in capacity building of local CPR institutions as a matter of urgency in order to deal effectively with subsistence poaching, particularly in Mozambique where subsistence hunting behavior is still prevalent. Information, training related to NRM in general or wildlife management in particular, and awareness campaigns could be used by policy makers to influence people's perceptions, which in turn affect behavior and large-scale cooperation in the TFCA. However, the provision of resources, training, and skills required to combat wildlife crime is necessary for community institutions to perform efficiently and effectively. Furthermore, the philosophy of community-based polices needs to move away from the traditional view of recruiting volunteers as resource monitors toward creating a more stable form of employment that is supported by the proceeds from conservation. Finally, the process of generating, sharing, and utilizing information for decision making should be transparent and inclusive of all important stakeholders.

${ }^{[1]}$ Furthermore, there have been very few attempts to quantify the cost associated with the loss of biodiversity due to subsistence poaching.

Responses to this article can be read online at: https://www.ecologyandsociety.org/issues/responses. $\mathrm{php} / 12201$

\section{Acknowledgments:}

We thank the communities around the Gonarezhou National Park in Zimbabwe, Limpopo National Park in Mozambique, and Kruger National Park in South Africa for their willingness to participate in the surveys. We are grateful to the Swedish Research Council (SRC) through the Centre for Collective Action Research (CeCAR) at the University of Gothenburg for funding the fieldwork. We are thankful for their financial support from Economic Research Southern Africa (ERSA). Last but not least, we acknowledge reviewers, colleagues, and friends for their useful comments. Earlier versions of this manuscript are published as ERSA and EfD working papers.

\section{Data Availability:}

The data that support the findings of this study are available on request from the corresponding author, $H N$. The data is not publicly available because it contains information that could compromise the privacy of research participants and the surveyed communities such as the utilization of environmental resources in the communities, buffer zone, and protected areas, which also include bushmeat consumption. In collecting this data, the researchers assured the participants that they will follow appropriate ethical principles and professionalism in handing the data to guarantee safety of the participants and their communities because bushmeat consumption is an illegal activity, i.e., the data will not be shared with anyone except for the purposes of this research. 


\section{LITERATURE CITED}

Agrawal, A. 2001. Common property institutions and sustainable governance of resources. World Development 29(10):1649-1672. https://doi.org/10.1016/S0305-750X(01)00063-8

Annecke, W., and M. Masubelele. 2016. A review of the impact of militarisation: the case of rhino poaching in Kruger National Park, South Africa. Conservation and Society 14:195-204. https:// doi.org/10.4103/0972-4923.191158

Ayling, J. 2013. What sustains wildlife crime? Rhino horn trading and the resilience of criminal networks. Journal of International Wildlife Law \& Policy 16(1):57-80. https://doi.org/10.1080/1388$\underline{0292.2013 .764776}$

Baerlein, T., U. Kasymov, and D. Zikos. 2015. Self-governance and sustainable common pool resource management in Kyrgyzstan. Sustainability 7:496-521. https://doi.org/10.3390/ $\underline{\text { su7010496 }}$

Baruch-Mordo, S., S. W. Breck, K. R. Wilson, and J. Broderick. 2011. The carrot or the stick? Evaluation of education and enforcement as management tools for human-wildlife conflicts. PLoS ONE 6(1):e15681. https://doi.org/10.1371/journal.pone.0015681

Becchetti, L., S. Castriota, and P. Conzo. 2016. Social capital dynamics and collective action: the role of subjective satisfaction in a common pool resource experiment. Environment and Development Economics 21(4):512-531. https://doi.org/10.1017/ S1355770X15000340

Carter, N. H., J. V. López-Bao, J. T. Bruskotter, M. Gore, G. Chapron, A. Johnson, Y. Epstein, M. Shrestha, J. Frank, O. Ohrens, and A. Treves. 2017. A conceptual framework for understanding illegal killing of large carnivores. Ambio 46:251-264. https://doi.org/10.1007/s13280-016-0852-Z

Challender, D. W. S., and D. C. MacMillan. 2014. Poaching is more than an enforcement problem. Conservation Letters 7 (5):484-494. https://doi.org/10.1111/conl.12082

Clark, C. W. 1990. Mathematical bioeconomics: the optimal management of renewable resources. Wiley, Hoboken, New Jersey, USA.

Cooney, R., D. Roe, H. Dublin, J. Phelps, D. Wilkie, A. Keane, H. Travers, D. Skinner, D. W. S. Challender, J. R. Allan, and D. Biggs. 2017. From poachers to protectors: engaging local communities in solutions to illegal wildlife trade. Conservation Letters 10(3):367-374. https://doi.org/10.1111/conl.12294

Cornish, D., and R. Clarke. 2008. The rational choice perspective. Pages 21-47 in R. Wortley and L. Mazerolle, editors. Environmental criminology and crime analysis. Willan, Portland, Oregon, USA.

Engel, C., and P. G. Moffatt. 2014. Dhreg, Xtdhreg, and Bootdhreg: commands to implement double-hurdle regression. Stata 14(4):778-797. https://doi.org/10.1177/1536867X1401400405

Fischer, C., E. Muchapondwa, and T. Sterner. 2011. A bioeconomic model of community incentives for wildlife management under CAMPFIRE. Environmental and Resource Economics 48(2):303-319. https://doi.org/10.1007/s10640-010-9409$\mathrm{y}$
Gandiwa, E. 2011. Preliminary assessment of illegal hunting by communities adjacent to the northern Gonarezhou National Park, Zimbabwe. Tropical Conservation Science 4(4):445-467. https://doi.org/10.1177/194008291100400407

Gandiwa, E., I. M. A. Heitkönig, A. M. Lokhorst, H. H. T. Prins, and C. Leeuwis. 2013. Illegal hunting and law enforcement during a period of economic decline in Zimbabwe: a case study of northern Gonarezhou National Park and adjacent areas. Journal for Nature Conservation 21:133-142. https://doi.org/10.1016/j. jnc.2012.11.009

Givá, N., and K. Raitio. 2017. 'Parks with people' in Mozambique: community dynamic responses to human-elephant conflict at Limpopo National Park. Journal of Southern African Studies 43(6):1199-1214. https://doi.org/10.1080/03057070.2017.1374810

Harrison, M., D. Roe, J. Baker, G. Mwedde, H. Travers, A. Plumptre, A. Rwetsiba, and E. J. Milner-Gulland. 2015. Wildlife crime: a review of the evidence on drivers and impacts in Uganda. International Institute for Environment and Development, London, UK.

Hasanov, M., and C. Zuidema. 2018. The transformative power of self-organization: towards a conceptual framework for understanding local energy initiatives in The Netherlands. Energy Research \& Social Science 37:85-93. https://doi.org/10.1016/j. erss.2017.09.038

Homans, G. C. 1958. Social behaviour as exchange. American Journal of Sociology 63(6):597-606.

Hübschle, A. 2016. A game of horns: transnational flows of rhino horn. Dissertation. International Max Planck Research School on the Social and Political Constitution of the Economy, Cologne, Germany.

Hübschle, A. 2017. The social economy of rhino poaching: of economic freedom fighters, professional hunters and marginalized local people. Current Sociology 65(3):427-447. https://doi.org/10.1177/0011392116673210

Johannesen, A. B., and A. Skonhoft. 2004. Property rights and natural resource conservation. A bio-economic model with numerical illustrations from the Serengeti-Mare ecosystem. Environmental and Resource Economics 28:469-488. https://doi. org/10.1023/B:EARE.0000036774.15204.49

Kahler, J. S., and M. L. Gore. 2012. Beyond the cooking pot and pocket book: factors influencing noncompliance with wildlife poaching rules. International Journal of Comparative and Applied Criminal Justice 36(2):103-120. https://doi.org/10.1080/0192403$\underline{6.2012 .669913}$

Kahler, J. S., G. J. Roloff, and M. L. Gore. 2013. Poaching risks in community-based natural resource management. Conservation Biology 27(1):177-186. https://doi.org/10.1111/j.1523-1739.2012.01960. $\underline{\mathrm{X}}$

Keane, A., J. P. G. Jones, G. Edwards-Jones, and E. J. MilnerGulland. 2008. The sleeping policeman: understanding issues of enforcement and compliance in conservation. Animal Conservation 11:75-82. https://doi.org/10.1111/j.1469-1795.2008.00170. $\underline{\mathrm{X}}$ 
Kideghesho, J. 2016. The elephant poaching crisis in Tanzania: a need to reverse the trend and the way forward. Tropical Conservation Science 9(1):369-388. https://doi.org/10.1177/1940$\underline{08291600900120}$

Kiffner, C., L. Peters, A. Stroming, and J. Kioko. 2015. Bushmeat consumption in the Tarangire-Manyara ecosystem, Tanzania. Tropical Conservation Science 8(2):318-332. https://doi. org/10.1177/194008291500800204

Knapp, E. J. 2012. Why poaching pays: a summary of risks and benefits illegal hunters face in Western Serengeti, Tanzania. Tropical Conservation Science 5(4):434-445. https://doi. org/10.1177/194008291200500403

Knell, R. J., and C. Martínez-Ruiz. 2017. Selective harvest focused on sexual signal traits can lead to extinction under directional environmental change. Proceedings of the Royal Society B: Biological Sciences 284(1868). https://doi.org/10.1098/rspb.2017.1788

Leader-Williams, N., and E. J. Milner-Gulland. 1993. Policies for the enforcement of wildlife laws: the balance between detection and penalties in Luangwa Valley, Zambia. Conservation Biology 7(3):611-617. https://doi.org/10.1046/j.1523-1739.1993.07030611. $\underline{\mathrm{x}}$

Lindsey, P. A., G. Balme, M. Becker, C. Begg, C. Bento, C. Bocchino, A. Dickman, R. W. Diggle, H. Eves, P. Henschel, D. Lewis, K. Marnewick, J. Mattheus, J. W. McNutt, R. McRobb, N. Midlane, J. Milanzi, R. Morley, M. Murphree, V. Opyene, J. Phadima, G. Purchase, D. Rentsch, C. Roche, J. Shaw, H. van der Westhuizen, N. Van Vliet, and P. Zisadza-Gandiwa. 2013. The bushmeat trade in African savannas: impacts, drivers, and possible solutions. Biological Conservation 160:80-96. https://doi. org/10.1016/j.biocon.2012.12.020

Lunstrum, E. 2013. Articulated sovereignty: extending Mozambican state power through the Great Limpopo Transfrontier Park. Political Geography 36:1-11. https://doi. org/10.1016/j.polgeo.2013.04.003

Lunstrum, E. 2016. Green grabs, land grabs and the spatiality of displacement: eviction from Mozambique's Limpopo National Park. Area 48(2):142-152. https://doi.org/10.1111/area.12121

Lunstrum, E., and N. Givá. 2020. What drives commercial poaching? From poverty to economic inequality. Biological Conservation 245:108505. https://doi.org/10.1016/j.biocon.2020.108505

Mabele, M. B. 2017. Beyond forceful measures: Tanzania's 'war on poaching' needs diversified strategies more than militarized tactics. Review of African Political Economy 44(153):487-498. https://doi.org/10.1080/03056244.2016.1271316

Massé, F. 2016. The political ecology of human-wildlife conflict: producing wilderness, insecurity, and displacement in the Limpopo National Park. Conservation and Society 14(2):100-111. https://doi.org/10.4103/0972-4923.186331

Massé, F., A. Gardiner, R. Lubilo, and M. N. Themba. 2017. Inclusive anti-poaching? Exploring the potential and challenges of community-based anti-poaching. South African Crime Quarterly 60:19-27. https://doi.org/10.17159/2413-3108/2017/ $\underline{\mathrm{v} 0 \mathrm{n} 60 \mathrm{a} 1732}$
Massé, F. and E. Lunstrum. 2016. Accumulation by securitization: commercial poaching, neoliberal conservation, and the creation of new wildlife frontiers. Geoforum 69:227-237. https://doi.org/10.1016/j.geoforum.2015.03.005

Mavhunga, C. C. 2014. Transient workspaces: technologies of everyday innovation in Zimbabwe. MIT Press, Cambridge, Massachusetts, USA. https://doi.org/10.7551/mitpress/9780262$\underline{027243.001 .0001}$

Milgroom, J. 2015. Policy processes of a land grab: at the interface of politics 'in the air' and politics 'on the ground' in Massingir, Mozambique. Journal of Peasant Studies 42(3-4):585-606. http:// dx.doi.org/10.1080/03066150.2014.991721

Milgroom, J., and M. Spierenburg. 2008. Induced volition: resettlement from the Limpopo National Park, Mozambique. Journal of Contemporary African Studies 26(4):435-448. http://dx. doi.org/10.1080/02589000802482021

Milner-Gulland, E. J., and N. Leader-Williams. 1992. A model of incentives for the illegal exploitation of black rhinos and elephants: poaching pays in Luangwa Valley, Zambia. Journal of Applied Ecology 29:388-401. https://doi.org/10.2307/2404508

Miller, B. W., S. C. Caplow, and P. W. Leslie. 2012. Feedbacks between conservation and social-ecological systems. Conservation Biology 26(2):218-227. https://doi.org/10.1111/j.1523-1739.2012.01823. $\underline{\mathrm{X}}$

Moreto, W. D., and A. M. Lemieux. 2015. Poaching in Uganda: perspectives of law enforcement rangers. Deviant Behavior 36 (11):853-873. https://doi.org/10.1080/01639625.2014.977184

Muboko, N. 2017. The role of transfrontier conservation areas and their institutional framework in natural resource-based conflict management: a review. Journal of Sustainable Forestry 36 (6):583-603. https://doi.org/10.1080/10549811.2017.1320224

Muchapondwa, E., and J. Stage. 2015. Whereto with institutions and governance challenges in African wildlife conservation? Environmental Research Letters 10:095013. https://doi. org/10.1088/1748-9326/10/9/095013

Ntuli, H., S. C. Jagers, A. Linell, M. Sjöstedt, and E. Muchapondwa. 2019. Factors influencing local communities' perceptions towards conservation of transboundary wildlife resources: the case of the Great Limpopo Trans-frontier Conservation Area. Biodiversity and Conservation 28:2977-3003. https://doi.org/10.1007/s10531-019-01809-5

Ntuli, H., and E. Muchapondwa. 2017. Effects of wildlife resources on community welfare in Southern Africa. Ecological Economics 131:572-583. https://doi.org/10.1016/j.ecolecon.2016.09.004

Ntuli, H., and E. Muchapondwa. 2018. The role of institutions in community wildlife conservation in Zimbabwe. International Journal of the Commons 12(1):134-169. https://doi.org/10.18352/ ijc. 803

Obour, R., R. Asare, P. Ankomah and T. Larson. 2016. Poaching and its potential to impact wildlife tourism: an assessment of poaching trends in the Mole National Park in Ghana. Athens Journal of Tourism 3(3):169-192. https://doi.org/10.30958/ ajt.3-3-1 
Ostrom, E. 1990. Governing the commons: the evolution of institutions for collective action. Cambridge University Press, New York, New York, USA.

Ostrom, E. 2007. A diagnostic approach for going beyond panaceas. Proceedings of the National Academy of Sciences of the United States of America 104(39):15181-15187. https://doi. org/10.1073/pnas.0702288104

Ostrom, E. 2010. Analysing collective action. Agricultural Economics 41(s1):155-166. https://doi.org/10.1111/j.1574-0862.2010.00497. $\underline{\mathrm{X}}$

Ostrom, E., M. A. Janssen, and J. M. Anderies. 2007. Going beyond panaceas. Proceedings of the National Academy of Sciences of the United States of America 104(39):15176-15178. https://doi.org/10.1073/pnas.0701886104

Perman, R., Y. Ma, J. McGilvray, and M. Common. 2003. Natural resource and environmental economics. Third edition. Pearson Education Limited, Harlow, UK.

Saunders, F. P. 2014. The promise of common pool resource theory and the reality of commons projects. International Journal of the Commons 8(2):636-656. https://doi.org/10.18352/ijc.477

Schulte-Herbrüggen, B., G. Cowlishaw, K. Homewood, and J. M. Rowcliffe. 2013. The importance of bushmeat in the livelihoods of West African cash-crop farmers living in a faunally-depleted landscape. PLoS ONE 8(8):e72807. https://doi.org/10.1371/ journal.pone.0072807

Steffen, W. R. 2012. Rio+20: Another step on the journey towards sustainability. The Conversation, 29 June. [online] URL: http:// theconversation.edu.au/rio-20-another-step-on-the-journey-towardssustainability-7885

Sundström, A., A. Linell, H. Ntuli, M. Sjöstedt, and M. L. Gore. 2020. Gender differences in poaching attitudes: insights from communities in Mozambique, South Africa, and Zimbabwe living near the great Limpopo. Conservation Letters 13(1):e12686. https://doi.org/10.1111/conl.12686

't Sas-Rolfes, M. 2017. African wildlife conservation and the evolution of hunting institutions. Environmental Research Letters 12:115007. https://doi.org/10.1088/1748-9326/aa854b

't Sas-Rolfes, M., D. W. S. Challender, A. Hinsley, D. Veríssimo, and E. J. Milner-Gulland. 2019. Illegal wildlife trade: scale, processes, and governance. Annual Review of Environment and Resources 44:201-228. https://doi.org/10.1146/annurevenviron-101718-033253

Tchakatumba, P. K., E. Gandiwa, E. Mwakiwa, B. Clegg, and S. Nyasha. 2019. Does the CAMPFIRE programme ensure economic benefits from wildlife to households in Zimbabwe? Ecosystems and People 15(1):119-135. https://doi. org/10.1080/26395916.2019.1599070

Tranquilli, S., M. Abedi-Lartey, K. Abernethy, F. Amsini, A. Asamoah, C. Balangtaa, S. Blake, E. Bouanga, T. Breuer, T. M. Brncic, et al. 2014. Protected areas in tropical Africa: assessing threats and conservation activities. PLOS ONE 9(12):e114154. https://doi.org/10.1371/journal.pone.0114154
Witter, R., and T. Satterfield. 2019. Rhino poaching and the "slow violence" of conservation-related resettlement in Mozambique's Limpopo National Park. Geoforum 101:275-284. https://doi. org/10.1016/j.geoforum.2018.06.003

Yen, S. T., and C. L. Huang. 1996. Household demand for finfish: a generalized double-hurdle model. Journal of Agricultural and Resource Economics 21(2):220-234. 


\section{APPENDIX 1}

\section{Justification for including the poaching behaviour in the community}

These could be incidences described by communities as (de facto) legitimate harvesting when they in fact constitute (de jure) poaching. Realizing this is important if one wants reliable responses about poaching in communities. During the interview stage, we did not make any judgement on whether communities were poaching or not. Communities themselves had to give the label to the type of harvesting occurring in their area. However, while analysing data, the study would classify any wildlife harvesting conducted in areas where the law forbids it as subsistence poaching.

\section{Further information about sampling}

We used systematic random sampling in each cluster whereby, from the list of households in every village, we randomly selected every $n^{\text {th }}$ household where $n$ is the sampling interval calculated as the total number of households in the community divided by the required sample size for that community.

Upon entering a village, enumerators randomly selected a starting point and direction by flipping a coin and tossing a dice simultaneously. Our procedure ensured that chiefs and local authorities did not influence the sampling process by recommending some villages over others.

\section{Enumerator training}

The enumerators were trained for two days during which they got the opportunity to go through the survey to get familiar with the questions and the sampling procedure. In order to test the applicability of the questionnaire and sampling, a pilot round was conducted on the third day in one village before the main data collection started in each country.

\section{Focus Group Discussion (FGDs) and Key Informant Interviews}

Regarding the qualitative component, we recruited participants for the FGDs with help from traditional leaders. Participants came from the different segments of the society taking into consideration gender, level of education and their wealth status. We also made sure that all communities surveyed in the study area were well represented in these dimensions. A total of nine FGDs were conducted, three in each country with the average group size of ten participants. For the key informant interviews, we used a snowballing approach to identify the next key informant, which resulted in five interviews in total. An interview guide with both specific and probing questions was used allowing also new discussions to emerge while at the same time making sure that derailment from the main focus of the study did not occur. The discussions were on average 45 minutes long and we actively tried to keep them at this length as to avoid fatigue. 


\section{Empirical model specification}

Dependent variables used in Model 1: The survey item reads: "How many poaching events have you heard about during the recent year?" Respondents are given the following response options; please state number (_).

Justification for the dependent variable in Model 1: In deciding on the number to report, each respondent recalls community-level poaching data based on the poaching they have witnessed as well as the poaching they have been reliably informed about. The only element missing from their reported data is their own poaching, that is if they happen to poach. This strategy gives a more reliable estimate of poaching as the sample size increases than if each respondent was asked to report their own poaching statistics. Our assumption is that understanding individual perceptions about group behaviour provides some important

\section{Justification for the using Craggs model}

The difference between the Heckman and Craggs model is that the former assumes that in the second stage, there will be no zero observations once the first stage is passed, whereas the Craggs double hurdle still considers that there might be a possibility of a zero observation which might arise from the individual's choices or random circumstances (ibid). For the Heckman model, we interpret the case of the positive values only because the zero values are problematic as they include liars, while for the Craggs double hurdle model we interpret both the positive and zero values (Engel and Moffatt 2014). The Heckman model is largely useful for controlling sample selection bias.

Dependent variables used in Model 2: This survey item asks: "When was the last time you or any member of this household went out to hunt?" Respondents are given the following response options; please specify year (__ and/or month (__ $)$ if quite recent.

Justification for the dependent variable in Model 2: All forms of hunting by local communities are generally considered as subsistence poaching since hunting is strictly forbidden by law in the study area. Thus, asking local communities about their previous hunting behaviour does not affect the analysis of correlation between subsistence poaching and the drivers identified in the literature, and the subsequent policy recommendations, since hunting is synonymous with poaching in these areas. To avoid protests from respondents who believe they have a right to hunt for one reason or another despite the de jure hunting ban instituted by the government, this question came first in the questionnaire.

\section{Computation of the dependent variable for the second model}

If we define a natural cut-off point linked to the CBNRM regime shift as the difference between the survey period and the year of establishment of the community conservation project, the dependent variable for the logit model is re-defined as follows:

$$
A_{i}=\left\{\begin{array}{l}
1 \text { if years } \leq C \\
0 \text { if years }>C
\end{array}\right.
$$


where $\mathrm{C}$ = year of establishment - survey period (May 2017, Aug 2018) and $\mathrm{A}_{\mathrm{i}}$ equals 0 if the number of years the household was actively involved in hunting is greater than $\mathrm{C}$ and 1 otherwise. We chose this natural cut-off point because it is exogenous to the system in the sense that beneficiaries were not able to influence it. Therefore, if CBNRM reduced subsistence poaching, then we would want to know whether a household ceased poaching after its inception. For the case of Mozambique, we used the year the household was removed from the park and relocated to the village where they are staying now as the year of establishment of the CBNRM.

\section{Computation of the indices}

All categorical variables and variables that require respondents to rate from 1 to 10 (i.e, the use of a Likert scale) were converted into binary variables (median-split) and the computed index is expressed as a fraction between zero and one for ease of interpretation. For instance, a categorical question was recorded into two values, i.e., zero if the response is negative (or below average on a Likert scale) and 1 if it is positive (or average and above on a Likert scale). Negative questions were recorded to match questions that were asked in a positive sense. This was done so that the index lies between 0 and 1 and is easy to read, where zero signifies a negative outcome and one stands for a positive outcome. 
Table A1.1. Type of question asked by theme.

\begin{tabular}{|c|c|}
\hline Theme & Type of questions \\
\hline \multicolumn{2}{|c|}{ Dependent variables } \\
\hline \multirow[t]{3}{*}{$\begin{array}{l}\text { Perception of } \\
\text { benefits }\end{array}$} & $\begin{array}{l}\text { Does the rules from "the park" benefit you, for instance by generating income or } \\
\text { employment? } 0=\text { No } 1=\text { Yes }\end{array}$ \\
\hline & $\begin{array}{l}\text { Does your community receive any income from recreational hunting in the area? } 0= \\
\text { No } 1=\text { Yes }\end{array}$ \\
\hline & $\begin{array}{l}\text { To what extent do you believe that these economic benefits will be distributed fairly? } \\
1=\text { Not at all } 2=\text { To a limited extent } 3=\text { To some extent } 4=\text { To a great extent }\end{array}$ \\
\hline \multirow[t]{11}{*}{$\begin{array}{l}\text { Perception of } \\
\text { rules }\end{array}$} & $\begin{array}{l}\text { How willing are you to follow the rules of the park? } \\
1=\text { Not at all willing } 2=\text { Not willing } 3=\text { Neither willing nor reluctant } 4=\text { Willing } 5= \\
\text { Very willing }\end{array}$ \\
\hline & $\begin{array}{l}\text { To what extent do you consider violating the rules of the park? } \\
1=\text { do not consider it at all } 2=\text { do not consider it } 3=\text { neither willing nor reluctant } 4= \\
\text { to some extent } 5=\text { to a large extent }\end{array}$ \\
\hline & $\begin{array}{l}\text { In general, to what extent do you actually obey the regulations of the park? } \\
1=\text { Not at all } 2=\text { To a limited extent } 3=\text { To some extent } 4=\text { To a large extent } 5=\text { To } \\
\text { a complete extent }\end{array}$ \\
\hline & Rules governing the park are clear and simple to understand $0=$ No, $1=$ Yes \\
\hline & You are well informed about the park and its rules? $0=$ No, $1=$ Yes \\
\hline & Rules governing the park intend doing the right thing $0=$ No, $1=$ Yes \\
\hline & Rules governing the park are enforced fairly $0=$ No, $1=$ Yes \\
\hline & There is a moral obligation to comply with the rules governing the park $[0,1]$ \\
\hline & A person would feel shame if caught for violating the rules governing the park \\
\hline & Local communities are involved in the making of rules governing the park $[0,1]$ \\
\hline & Authorities listen to local communities when designing rules governing the park \\
\hline \multirow[t]{6}{*}{$\begin{array}{l}\text { Perception of } \\
\text { wildlife }\end{array}$} & $\begin{array}{l}\text { What the people and its livestock need is more important than saving plants and wild } \\
\text { animals? } 0=\text { No, } 1=\text { Yes }\end{array}$ \\
\hline & It is important to protect wildlife for our children $0=$ No, $1=$ Yes \\
\hline & $\begin{array}{l}\text { There are so many wild animals nowadays that the laws to protect them are no longer } \\
\text { necessary } 0=\text { No, } 1=\text { Yes }\end{array}$ \\
\hline & Wildlife and nature in the area of the park is in risk of being depleted \\
\hline & Wildlife is nowadays more abundant than it used to be \\
\hline & In recent time, the overall threats to wildlife and resources have increased \\
\hline
\end{tabular}




\begin{tabular}{|c|c|}
\hline & Has your property or any person you know been damaged by wildlife? $[0,1]$ \\
\hline \multirow{15}{*}{$\begin{array}{l}\text { Perception of } \\
\text { environmental } \\
\text { crime }\end{array}$} & $\begin{array}{l}\text { Collecting firewood in a protected area } \\
1=\text { Not wrong } 2=\text { Wrong but understandable } 3=\text { Wrong and should be punished }\end{array}$ \\
\hline & $\begin{array}{l}\text { Collecting firewood in a protected area } \\
1=\text { Not wrong } 2=\text { Wrong but understandable } 3=\text { Wrong and should be punished }\end{array}$ \\
\hline & $\begin{array}{l}\text { Shooting an animal that destroys your crops } \\
1=\text { Not wrong } 2=\text { Wrong but understandable } 3=\text { Wrong and should be punished }\end{array}$ \\
\hline & $\begin{array}{l}\text { Fishing although there is a closed season } \\
1=\text { Not wrong } 2=\text { Wrong but understandable } 3=\text { Wrong and should be punished }\end{array}$ \\
\hline & $\begin{array}{l}\text { Poaching inyalas or impalas for bushmeat } \\
1=\text { Not wrong } 2=\text { Wrong but understandable } 3=\text { Wrong and should be punished }\end{array}$ \\
\hline & $\begin{array}{l}\text { Has illegal hunting increased or decreased during recent years? } \\
1=\text { decreased } 2=\text { not changed } 3=\text { Increased }\end{array}$ \\
\hline & $\begin{array}{l}\text { How many poaching events have you heard about during the recent year? } \\
0 \text { if less than three and } 1 \text { if greater than } 3\end{array}$ \\
\hline & Most poachers in this area never get caught \\
\hline & It is sometimes justified to harbour a poacher in your house \\
\hline & $\begin{array}{l}\text { You would tell authorities if you had information that could send a poacher in front } \\
\text { of the legal system to face sanctions }\end{array}$ \\
\hline & Poaching for commercial use is morally wrong \\
\hline & Poaching for subsistence use is morally wrong \\
\hline & Collecting firewood, although illegal, is morally acceptable \\
\hline & People engaged in poaching should face harder sentences \\
\hline & $\begin{array}{l}\text { If a poacher comes from another country then it is more acceptable to tell the } \\
\text { police about this person }\end{array}$ \\
\hline \multicolumn{2}{|c|}{ Explanatory variables } \\
\hline \multirow[t]{4}{*}{$\begin{array}{l}\text { Park } \\
\text { management }\end{array}$} & $\begin{array}{l}\text { What are your opinions about the current management of the park? } \\
5=\text { Very good } 4=\text { Good } 3=\text { Neither good nor bad } 2=\text { Bad } 1=\text { Very bad }\end{array}$ \\
\hline & $\begin{array}{l}\text { How common is it that local communities are involved in monitoring rules governing } \\
\text { the park? } 1=\text { Very rare } 2=\text { Rare } 3=\text { Common } 4=\text { Very common }\end{array}$ \\
\hline & $\begin{array}{l}\text { How effective is enforcement to reduce violations? } \\
1=\text { Not effective at all } 2=\text { Somewhat effective } 3=\text { Effective } 4=\text { Very effective }\end{array}$ \\
\hline & How much of illegal behaviour related to conservation in your area will the rangers \\
\hline
\end{tabular}




\begin{tabular}{|c|c|}
\hline & $\begin{array}{l}\text { generally be able to hinder? } \\
1=\text { Nothing } 2=\text { Hardly anything of it } 3=\text { Some of it } 4=\text { Most of it }\end{array}$ \\
\hline & $\begin{array}{l}\text { How often are you in contact with rangers or other state employees enforcing the park } \\
\text { rules? } \\
1=\text { Less than once a year } 2=\text { On some occasions over a year } \\
3=\text { Every month } 4 \text { = Every week } 5=\text { Almost daily }\end{array}$ \\
\hline & $\begin{array}{l}\text { Rangers from your country are more efficient than rangers from neighbouring } \\
\text { countries }\end{array}$ \\
\hline & Help park rangers in their surveillance by telling them of suspicious activities \\
\hline & A joint ranger force with staff from all the countries engaged in the TFCA \\
\hline & Surveillance of poaching activities should be increased \\
\hline & $\begin{array}{l}\text { Are you ever in contact with enforcement officers from other countries? } \\
0=\text { No } 1=\text { Yes }\end{array}$ \\
\hline \multirow[t]{5}{*}{ Corruption } & $\begin{array}{l}\text { Offering a bribe to avoid being arrested by the police } \\
1=\text { Not wrong } 2=\text { Wrong but understandable } 3=\text { Wrong and should be punished }\end{array}$ \\
\hline & You personally know some of the rangers $[0,1]$ \\
\hline & Rangers are on friendly terms with your community $[0,1]$ \\
\hline & You can pay rangers them to make refrain to impose sanctions for rule violations \\
\hline & $\begin{array}{l}\text { Rangers from your country are more easily bribed than rangers from neighboring } \\
\text { countries }\end{array}$ \\
\hline \multirow[t]{4}{*}{ Expertise } & $\begin{array}{l}\text { Do you consider yourself or anyone else in the household to be a hunter? } \\
0=\text { No } 1=\text { Yes }\end{array}$ \\
\hline & $\begin{array}{l}\text { Do you consider yourself or anyone else in the household to be a fisherman? } \\
0=\text { No } 1=\text { Yes }\end{array}$ \\
\hline & $\begin{array}{l}\text { Do you consider yourself or anyone else in the household to be reliant on activities } \\
\text { that consist of using natural resources? } 0=\text { No } 1=\text { Yes }\end{array}$ \\
\hline & $\begin{array}{l}\text { How many times have you eaten bushmeat within the previous month? (state a } \\
\text { number) } 0 \text { if less than } 5 \text { times and } 1 \text { if greater or equal to five }\end{array}$ \\
\hline
\end{tabular}

